Research Article

\title{
Moderated effect of teachers' attitudes to the contribution of technology competencies on TPACK
}

Hendra Yulisman a,1, ${ }^{*}$, Ari Widodo a,2, Riandi a,3, Cut Intan Evtia Nurina a,4

a Master's Program in Science Education, School of Postgraduates, Universitas Pendidikan Indonesia, Jl. Dr. Setiabudhi No.229,

Bandung City, West Java 40154 Indonesia

${ }^{1}$ hendra.yulisman@fkip.unsyiah.ac.id*; ${ }^{*}$ widodo@upi.edu; ${ }^{3}$ rian@upi.edu; ${ }^{4}$ cutintanevtia@student.upi.edu

* Corresponding author

\begin{tabular}{|c|c|}
\hline ARTICLE INFO & ABSTRACT \\
\hline \multirow[t]{2}{*}{$\begin{array}{l}\text { Article history } \\
\text { Received March 06, } 2019 \\
\text { Revised April 16, } 2019 \\
\text { Accepted May 26, } 2019 \\
\text { Published June 30, } 2019 \\
\text { Keywords } \\
\text { Science teacher's TPACK } \\
\text { Teacher's attitudes } \\
\text { Technology competencies }\end{array}$} & $\begin{array}{l}\text { Technological Pedagogical and Content Knowledge (TPACK) can be seen as teacher's } \\
\text { skills and abilities in choosing and using technology effectively. However, information } \\
\text { about the teacher's attitudes contribution to technology competencies and science } \\
\text { teacher's TPACK is still limited. Therefore, this study aimed to analyze the relationship } \\
\text { between teacher's technology competencies and their TPACK as well as the effect of } \\
\text { teacher's attitudes as a moderating effect on relation between these two variables. This } \\
\text { survey research used total sampling technique which involved } 88 \text { science teachers from } \\
\text { junior high school of Kota Banda Aceh. The instruments consisted of questionnaires } \\
\text { and multiple-choice test which were distributed directly to the teachers. The data } \\
\text { analysis was performed by using the Partial Least Square approach. The results } \\
\text { showed that technology competencies have a positive relation to TPACK; likewise, the } \\
\text { teachers' attitudes in technology integration were able to strengthen the positive relation } \\
\text { between technology competency and science teacher's TPACK. Therefore, teacher's } \\
\text { attitude is an important factor should be concerned in improving teacher's TPACK. }\end{array}$ \\
\hline & $\begin{array}{l}\text { Copyright } \odot \text { 2019, Yulisman et al } \\
\text { This is an open access article under the CC-BY-SA license }\end{array}$ \\
\hline $\begin{array}{l}\text { contributi } \\
\text { https://do }\end{array}$ & $\begin{array}{l}\text {., Riandi, R., \& Nurina, C. I. E. (2019). Moderated effect of teachers' attitudes to t } \\
\text { competencies on TPACK. JPBI (Jurnal Pendidikan Biologi Indonesia), 5(2), 185-196. c } \\
\text { bi.v5i2.7818 }\end{array}$ \\
\hline
\end{tabular}

\section{INTRODUCTION}

Technology integration is a complex process that involves many interconnected factors, such as environmental, technology, individuals, organizations, and pedagogy (Niederhauser \& Lindstrom, 2018; Sánchez, Marcos, González, \& GuanLin, 2012). The success of technology integration cannot be seen only from the availability of technology. However, it must be seen from the teachers' skill and ability in choosing and using technology effectively that appropriate with learning content and pedagogy (Bilici, Guzey, \& Yamak, 2016). The appropriate technology integration model to describe such skill or ability is Technological Pedagogical and Content Knowledge (TPACK) (Chai, Koh, Tsai, \& Tan, 2011; Joo, Park, \& Lim, 2018).

TPACK framework consists of the main components and integration components (a combination of the main components). The main components consist of Content Knowledge (CK), Pedagogical Knowledge (PK), 
and Technological Knowledge (TK). Furthermore, the integration components consist of Pedagogical Content Knowledge (PCK), Technological Content Knowledge (TCK), Pedagogical Technology Knowledge (TPK), and Technological Pedagogical and Content Knowledge (TPACK) (Koehler, Mishra, \& Cain, 2013; Valtonen, Kukkonen, Kontkanen, Mäkitalo-Siegl, \& Sointu, 2018; Valtonen et al., 2017). These seven components are interrelated and cannot stand alone. Therefore, in order to have a good TPACK, a teacher must have the ability to develop fluency and cognitive flexibility in each of the main components and relationships between TPACK components. Finally, they can develop effective solutions in technology integration (Kimmons, 2015; Koehler et al., 2013).

The TPACK model is suitable to be used to describe and study the technological integration capabilities of teachers, especially teachers in Indonesia. The reason, several components of TPACK are part of the Indonesian professional teacher competencies that listed in the Standards Academic Qualification and Teacher Competencies in Indonesia. These components are pedagogical knowledge (related to pedagogical competence) and content knowledge (related to professional competence) (Nofrion, Wijayanto, Wilis, \& Novio, 2018). Furthermore, the TPACK model also consists of the PCK, which is the knowledge, experience, and skill that the teacher acquires through teaching experience in the classroom, which is a potential indicator of the teacher in implementing quality learning activities (Anwar, Rustaman, Widodo, \& Redjeki, 2014; Widodo, 2017).

As stated earlier, the integration of technology is influenced by several factors, one of which is an individual factor. Individual factor such as teachers' attitudes in technology integration and teachers' technology competencies can influence technology integration (Buabeng-Andoh, 2012; Karaca, Can, \& Yildirim, 2013; Yerdelen-Damar, Boz, \& Aydın-Günbatar, 2017). Attitude or the disposition of individuals to regulate thoughts, feelings, and behaviors towards psychological objects (Birkollu, Yucesoy, Baglama, \& Kanbul, 2017) is an indicator of the strength of their beliefs about the object and the critical aspect of those beliefs (Niederhauser \& Lindstrom, 2018). Positive teacher attitudes are significant predictors of the success of the teaching process. Therefore, if teachers have a positive attitude in technology integration, they can quickly adapt and integrate technology in teaching-learning processes and practices (Birkollu et al., 2017; Dalal, Archambault, \& Shelton, 2017; Huda, Yulisman, Nurina, Erni, \& Abdullah, 2018; Yanti, Setiawan, Nurhabibah, \& Yannuar, 2018).

Technology competence or the ability to handle various types of technology, both hardware, and software, for various purposes of learning activities is another factor influencing teachers' technology integration (Yerdelen-Damar et al., 2017). The results of the study showed that teachers who have a negative or neutral attitude towards the technology integration influenced by their knowledge and skills. They do not have sufficient knowledge and technology skills to integrate or choose the right technology into their learning activities (Baturay, Gökçearslan, \& Ke, 2017; Buabeng-Andoh, 2012).

According to Buabeng-Andoh (2012), teachers' positive attitude is a determinant in the thriving technology integration in learning activities despite obstacles such as lack of hardware and software. Furthermore, Kimmons and Hall (2018) states that teacher beliefs and values may have a stronger influence on the integration of integration than their knowledge. That is, the teachers' attitude can be a moderating effect on the successful integration of technology in learning activities. The moderating effect is caused by a moderator variable. The moderator variable is the secondary independent variable that chosen to determine whether the variable affects, changes the strength or even the direction of the relationship between the two constructs (Fraenkel, Wallen, \& Hyun, 2012; Hair, Hult, Ringle, \& Sarstedt, 2014).

In Indonesia, information about teachers' attitudes concerning technology competencies and science teachers' TPACK is still limited and focuses on descriptions. The previous studies limited on describing the competencies, experiences, and attitudes of teachers in technology integration (Huda et al., 2018), the perceptions of the lecturers in technology integration through mobile learning (Yulisman, 2017), and the teachers' ICT level (Miskiah, Suryono, \& Sudrajat, 2019). Furthermore, several studies on TPACK are also still in the scope of describing and focusing on certain materials, such as investigating experience in integrating technology and TPACK through training activities for science teachers (Agustin, Liliasari, Sinaga, \& Rochintaniawati, 2018) and English teachers (Drajati, Tan, Haryati, Rochsantiningsih, \& Zainnuri, 2018), knowing and analyzing the TPACK from Geography teachers (Nofrion et al., 2018) and English teachers (Mahdum, 2015), describing the TPACK ability of pre-service Physics teachers (Supriyadi, Bahri, \& Waremra, 2018), knowing the role of TPACK in designing learning (Sholihah \& Yuliati, 2016), and describing teachers' TPACK through animal physiology learning (Pusparini, Riandi, \& Sriyati, 2017).

Based on these studies, it appears that there was a gap to be filled between technology competencies and teachers' attitudes in technology integration with science teachers' TPACK. These variables have a relationship and influence each other. Also, there was no information about teachers' attitude in technology integration as a moderator variable on the relationship of technology competencies with TPACK. Therefore, by using the PLS approach, this study aimed to analyze the relationship of teacher technology competencies with their TPACK 
and the effect of teachers' attitudes as a moderating effect on the relations between technology competencies and TPACK.

\section{METHOD}

\section{Research design}

This research is quantitative with survey research design. The data collection method used a crosssectional survey.

\section{Research samples}

This research used total sampling technique involved all junior high school science teachers from Kota Banda Aceh. The teachers are from different educational backgrounds, namely Biology Education, Physics Education, and Chemical Education. Therefore, learning activity is conducted based on the teachers' background and learning material. For example, if there is a learning material related to biology, then teachers who will teach that subject is the teacher from Biology Education.

The teachers who became the sample of this research was the teacher sent by Education and Culture Office of Kota Banda Aceh. The total number of samples is 88 teachers (54 Biology teachers, 29 Physics teachers, 2 Science teachers, 1 Chemistry teachers, and two teachers from other backgrounds). The teachers are from 19 public junior high schools and nine private junior high schools. Furthermore, in order to obtain more in-depth information about the state of TPACK and the ability to integrate technology, researchers interviewed two teachers who are instructors, namely instructor of MGMP (teacher group) activities (Physics teacher, as well as the chairman of one of the Science MGMP in Banda Aceh) and instructor of multimedia usage in Aceh province (Biology teacher). This determination was based on their abilities, knowledge, and experience when becoming training instructors. Thus, the answers they gave were able to describe the state of the Banda Aceh science teachers.

\section{Instruments}

The definition of technology that used in the instruments of technology competencies and teacher attitudes in technology integration refers to the definition of technology according to Magana and Marzano (2014) namely electronic, digital, and multimedia devices that used to achieve goals effectively and efficiently. Furthermore, the definition of technology that used in TPACK instruments refers to Koehler et al. (2013) and Yerdelen-Damar (2017) stating that the word technology applies equally to analog and digital technologies or new and old technologies. However, they emphasize that the technology that used should be new and digital and have innate traits that require particular abilities in its use.

The data about teachers' attitudes in technology integration were obtained using a Likert scale questionnaire that consists of 19 questions. Each statement refers to five aspects, namely Strongly Agree, Agree, Neutral, Disagree, Strongly Disagree (Sugiyono, 2016). The attitude in technology integration is measured by using The Scale of Attitude Towards Technology developed by Birkollu et al. (2017) and Yavuz (2005).

The data about technology competencies were obtained using a multiple-choice test that consists of 17 questions. The question indicators were developed based on the Technology Competency scale developed by Karaca et al. (2013) and Yerdelen-Damar et al. (2017).

The science teachers' TPACK data was measured using 45 multiple choice test questions. The question indicators were made based on TPACK for $21^{\text {st }}$ Century Skills instrument (TPACK-21) (Valtonen et al., 2018, 2017) and TPACK survey for Meaningful Learning (Chai et al., 2011; Deng, Chai, So, Qian, \& Chen, 2017; Koh, Chai, \& Tsai, 2013). The development of this instrument was adjusted to science content and the integration of technology in pedagogically meaningful ways that are by the twenty-first-century skills framework (21stcentury skills framework) (Valtonen et al., 2017). Therefore, this instrument is suitable to be used to measure the TPACK of science teachers. Furthermore, this instrument observes the four capabilities needed in the $21^{\text {st }}$ century, namely the ability of communication, collaboration, critical thinking, and creative thinking (Valtonen et al., 2017; Valtonen, Sointu, Mäkitalo-Siegl, \& Kukkonen, 2015) and five meaningful learning dimensions such as active learning, cooperative learning, constructive learning, intentional learning, and authentic learning (Koh et al., 2013). In particular, indicators of the component of Content Knowledge (CK) and Pedagogy Knowledge (PK) refer to the Standards of Academic Qualification and Teacher Competencies (Standar Kualifikasi Akademik dan Kompetensi Guru) (Badan Standar Nasional Pendidikan, 2007).

Before being used, all of the three instruments were tested for validity and reliability on 55 teachers who have the same characteristics as science teachers. They have experience in teaching Biology, Chemistry, or 
Physics in high school. The trial instruments were distributed via the internet by using Google Form. The reliability test results showed that all of the three instruments have reliability requirements, namely 0.847 for science teachers' TPACK instrument, 0.622 for technology competency instrument, 0.775 for teachers' attitudes in technology integration instrument. Based on the validity test, several items excluded, namely two items from the science teachers' TPACK instrument, three items from the technology competencies instrument, and two items from the teachers' attitude in technology integration instrument.

\section{Instruments distribution and data analysis}

The research instruments were directly distributed to the teachers through technology integration training conducted in Faculty of Teacher Training and Education-Universitas Syiah Kuala. The training was initiated by researchers who collaborated with Faculty of Teacher Training and Education-Universitas Syiah Kuala and Education and Culture Office of Kota Banda Aceh.

Analysis of the moderating effect variable on the relationship between independent and dependent variables was evaluated by using the Structural Equational Modeling-Partial Least Square approach (known as SEM-PLS or called PLS). The PLS approach is suitable for prediction purposes. Also, PLS is not based on many assumptions, such as data does not have to be ordinarily multivariate (indicators with categories, ordinal scales, intervals, or ratios can be used on the same model) and do not require a large number of samples. Furthermore, PLS is not only suitable for prediction purposes but also can be used to explain whether there is a relationship between latent variables (Ghozali, 2014; Latan \& Ramli, 2013; Wong, 2013).

The data analysis started by summing the correct answers on the test item and the total score on the questionnaire for each indicator of research variables. Furthermore, the analysis of the relationship and the moderating effect was performed by using SEM-PLS with SmartPLS 3.2.8 software (Ringle, Wende, \& Becker, 2015).

\section{Research variables}

This research consists of three types of variables, namely exogenous variable (technological competencies), moderating variable (teachers' attitudes in technology integration), as well as an endogenous variable (science teachers' TPACK). The interaction of the three variables formed the following research model (Figure 1).

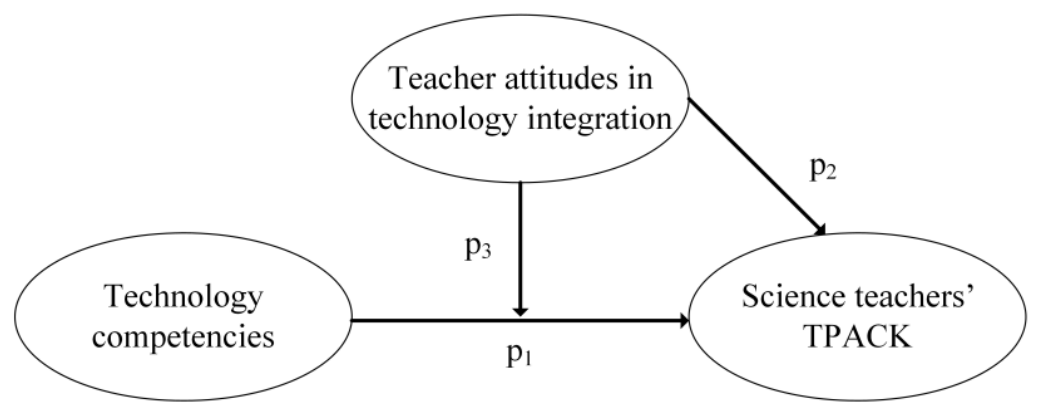

Figure 1. Research model with moderating effect

Table 1. The summary of evaluation of outer and inner models with reflective indicators

\begin{tabular}{ll}
\hline \multicolumn{1}{c}{ Criteria } & \multicolumn{1}{c}{ Rule of thumb } \\
\hline $\mathrm{FL}$ & $0.50-0.60$ \\
$\mathrm{AVE}$ & $>0.50$ \\
Cross Loading & $>0.70$ \\
The square root of AVE value and the & The square root of AVE > correlation between latent constructs \\
correlation between latent constructs & \\
$\mathrm{CR}$ & $>0.60$ \\
$\mathrm{R}^{2}$ & 0.67 (strong), 0.33 (moderate), and 0.19 (weak) \\
$\mathrm{f}^{2}$ & 0.35 (strong), 0.15 (moderate), and 0.02 (weak) \\
$\mathrm{Q}^{2}$ & $\mathrm{Q}^{2}>0$ represent the model has predictive relevance. \\
& $\mathrm{Q}^{2}<0$ represents the model has no predictive relevance. Furthermore, in order \\
& to obtain the value of $\mathrm{Q} 2$, we used the following formula. \\
& $\mathrm{Q}^{2}=1-\left(1-\mathrm{R}^{2}\right) \quad(1)$ \\
\hline
\end{tabular}




\section{Evaluation of PLS model}

The evaluation of the PLS model was performed by assessing the outer model and inner model. Evaluation of the outer model with reflective indicators consists of convergent validity, discriminant validity, and reliability. Convergent validity was obtained from the factor loading value and Average Value Extracted (AVE). Discriminant validity was obtained from the cross-loading value and compared the value from the square root of AVE with the correlation value between constructs. The reliability test that used and suitable for reflective indicators is Composite Reliability (CR) because the Cronbach's alpha value tends to be a lower bound estimate. Furthermore, the evaluation of the inner model was obtained from the value of $R^{2}$ for endogenous variable, effect size $\left(\mathrm{f}^{2}\right)$, and $\mathrm{Q}^{2}$ to determine the relevance of predictions from the models that have been designed (Ghozali, 2014; Ghozali \& Latan, 2015; Latan \& Ramli, 2013; Wong, 2013). The evaluation criteria for the PLS model shown in Table 1.

\section{RESULTS AND DISCUSSION}

The results of the PLS analysis are reported by using the two-step approach. The first step focused on reporting the results from the outer model. The second step focused on reporting the results from the inner model. Furthermore, because all indicators are reflective, the interaction approach that used was the product indicator (Ghozali \& Latan, 2015; Latan \& Ramli, 2013).

\section{The outer model evaluation results}

Evaluation of the outer model was performed twice. Based on the results of the first evaluation of the outer model (appendix), researchers excluded all indicators with loading values $<0.6$. It aimed to get a composite reliability value $>0.6$. After all indicators with values below 0.6 are excluded, re-estimation was performed. The re-estimation results shown in Figure 2.

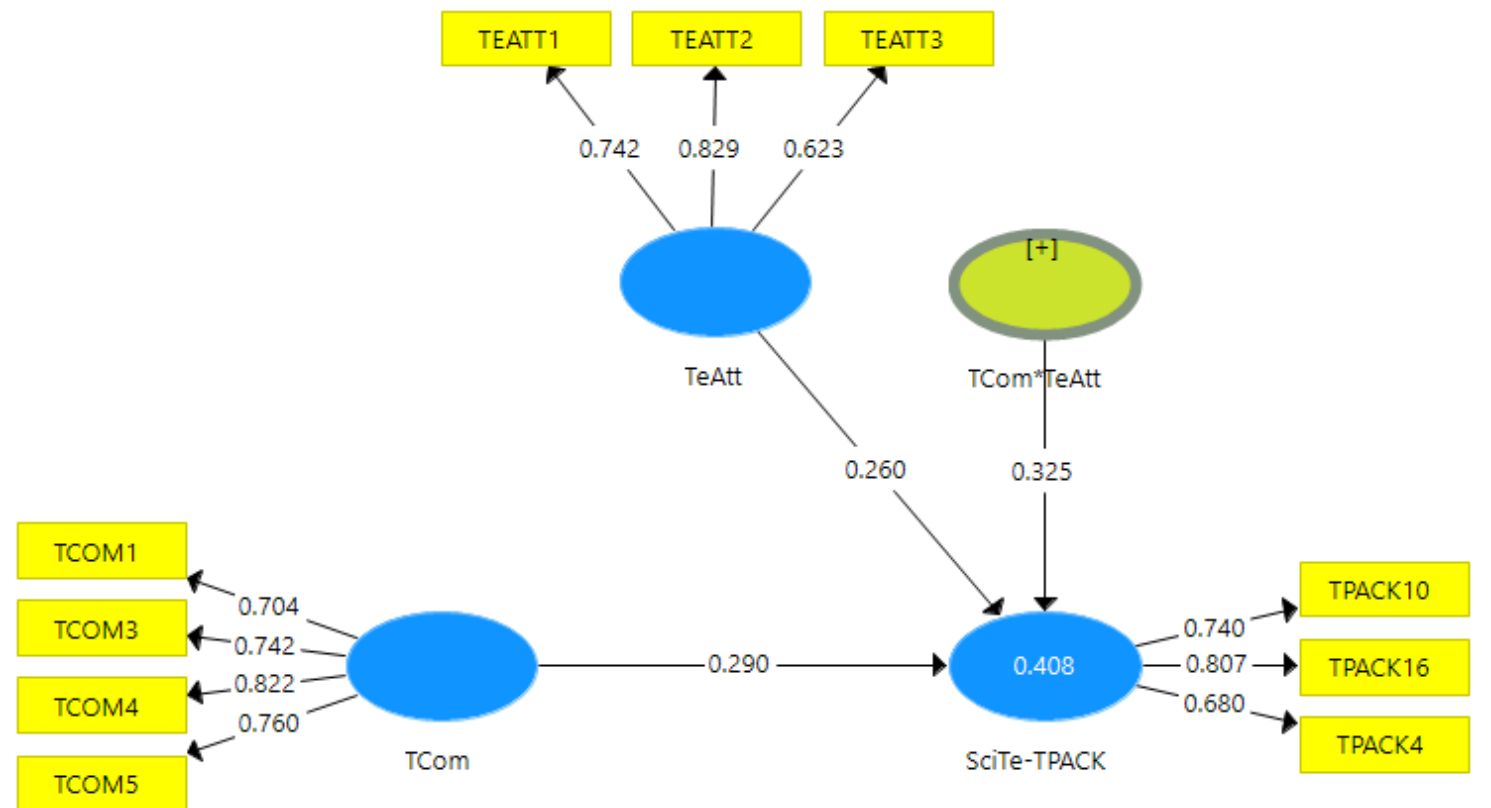

Figure 2. Graphical result of the outer model evaluation

The convergent validity value was determined from the factor loading and AVE values. The value of the factor loading (the correlation between the indicator and the latent construct) for each indicator used in the model must be higher than 0.60 . The results of evaluations (Table 2) showed that there are no indicators with a value below 0.5 . Furthermore, the AVE values for each construct must be higher than 0.5 . Table 2 showed that all constructs have AVE values greater than 0.5 .

The value of reliability in this research was obtained from the Composite Reliability (CR) value. This is caused by the value of Cronbach's alpha on SEM-PLS is lower (under-estimate) than the composite reliability value (Ghozali \& Latan, 2015; Wong, 2013). Based on Table 2, each of the research variables had a CR value greater than 0.7 . 
The determination of the discriminant validity was obtained from the value of cross-loading. However, because of the value of cross-loading is similar to the factor loading value, the researcher only showed the factor loading values. In the SmartPLS v3.2.8, comparison between the square root of AVE values and correlation values between constructs can be seen from the value of the Fornell-Larcker Criterium. The square root of AVE values is displayed diagonally, and the value below is the correlation value between constructs (Table 3). So, it showed that the values of the square root of AVE are higher than the correlation values; it can be concluded that the model is valid because it has met the discriminant validity. After all of the variables that used are valid and reliable, then proceed with a test of the influence between variables and moderating effects otherwise known as inner model evaluation.

Table 2. The results of convergent validity and reliability test

\begin{tabular}{lcccc}
\hline \multicolumn{1}{c}{ VAR $^{*}$} & Indicators & FL & AVE & CR \\
\hline SciTe-TPACK & TPACK4 & 0.680 & 0.554 & 0.787 \\
& TPACK10 & 0.740 & & \\
TCom & TPACK16 & 0.807 & 0.575 & 0.844 \\
& TCOM1 & 0.704 & & \\
& TCOM3 & 0.742 & & \multirow{2}{*}{0.778} \\
TCAtt & TCOM4 & 0.822 & 0.542 & \\
& TCOM5 & 0.760 & & \\
& TEATT1 & 0.742 & &
\end{tabular}

Table 3. Fornell-Larcker criterium for discriminant validity

\begin{tabular}{|c|c|c|c|}
\hline Variables & SciTe-TPACK & TCom & TeAtt \\
\hline SciTe-TPACK & 0.744 & & \\
\hline TCom & 0.461 & 0.758 & \\
\hline TeAtt & 0.482 & 0.416 & 0.736 \\
\hline
\end{tabular}

\section{The inner model evaluation results}

Evaluation of the inner model aims to see the significance of all path estimates. The predictive power of the outer model can be seen from the $\mathrm{R}^{2}$ value of the endogenous variable. Furthermore, in order to obtain the relevance of predictions, we determined by the value of $Q^{2}$ (1). In SmartPLS, $R^{2}$ value was obtained through PLS Algorithm.

Table 4. The $R^{2}$ value and rating from PLS algorithm result

\begin{tabular}{cccc}
\hline Variable & $\mathbf{R}^{2}$ & $\mathbf{R}^{2}$ adjusted & Rating \\
\hline SciTe-TPACK & 0.408 & 0.327 & Moderate \\
\hline
\end{tabular}

Based on $\mathrm{R}^{2}$ value (Table 4), it showed that $40.8 \%$ of science teachers' TPACK is influenced by technology competencies and teachers' attitudes in technology integration and the remaining $59.2 \%$ influenced by other variables outside of this research model. This is due to technology that used as indicators in technology competencies and the attitudes towards technology integration was information and communication technology. Meanwhile, the technology used as indicators in science teachers' TPACK consists of digital and analog technology. According to Koehler et al. (Koehler et al., 2013), technology in the TPACK can apply to all technology tools and resources. Therefore, not all technological capabilities within technology competencies and attitudes towards technology indicators affect science teachers' TPACK. The value of 0.408 also showed that the research model has a moderate rating.

Based on the calculation result (1), we obtained a $Q^{2}$ value of $0.408>0$, mean that the model built has predictive relevance. Specifically, when inner model evaluation results showed predictive relevance, it accurately predicts the data points of indicators in reflective inner models of endogenous constructs (Hair et al., 2014). Therefore, it exhibits that technology competencies and attitudes towards technology integration influencing science teachers TPACK in Banda Aceh. Furthermore, the values of effect size (Table 5) and path coefficient (Table 6) were obtained from the bootstrapping method through SmartPLS.

The results of bootstrapping about effect size (Table 5) showed that all of the variable relationships affect the science teachers' TPACK variable. However, only the relationship between technology competencies and teachers' attitudes has a moderate effect on science teacher TPACK, while the other two relationships have a 
weak effect. According to the description of $\mathrm{R}^{2}$ value, this result caused by the difference in technology in variable indicators. Interestingly, the combination of technological competencies and attitudes towards technology integration can improve relations with TPACK to become moderate. It showed that teachers could improve their TPACK if they have good technology competence and a positive attitude in integrating technology. According to Chow and Pepe (2015), the teachers will integrate technology into their learning activities if they feel that they have sufficient knowledge in the use of technology. Therefore, the government or schools should be investing more in a teacher's professional development rather than just purchasing pieces of technology.

Table 5. The effect size values from bootstrapping

\begin{tabular}{|c|c|c|}
\hline Relationships & $f^{2}$ & Description \\
\hline TCom $\rightarrow$ SciTe-TPACK & 0.117 & Weak \\
\hline TComTeAtt $\rightarrow$ SciTe-TPACK & 0.158 & Moderate \\
\hline TeAtt $\rightarrow$ SciTe-TPACK & 0.088 & Weak \\
\hline
\end{tabular}

Table 6. The path coefficient values from bootstrapping

\begin{tabular}{lccc}
\hline \multicolumn{1}{c}{ Relationships } & Mean & SD & t-statistics \\
\hline TCom $\rightarrow$ SciTe-TPACK & 0.29 & 0.09 & 3.22 \\
TCom ${ }^{*}$ TeAtt $\rightarrow$ SciTe-TPACK & 0.36 & 0.06 & 5.83 \\
TeAtt $\rightarrow$ SciTe-TPACK & 0.26 & 0.10 & 2.59 \\
\hline
\end{tabular}

The results of bootstrapping about path coefficients (Table 6) showed that all of the relationships have a value of $t$-statistics higher than $t$ table. It means all of the three relationships have a significant effect on the science teachers' TPACK. These results indicate that technology competency, attitudes towards technology integration, and the relationship of competence and attitudes in technology integration affect science teachers' TPACK. It showed that the better the competence and attitude of the teacher, the better the ability of their TPACK. These results support the previous research conducted by Yerdelen-Damar et al. (2017) and Karaca et al. (Karaca et al., 2013), showed that technology competence and attitudes towards technology integration have a significant effect on technology integration or in this study is the ability of their TPACK. Therefore, to improve the ability of science teachers' TPACK, it must notice their technological competencies and attitudes towards technology integration.

\section{The results of hypothesis testing}

The analysis of hypothesis testing was obtained based on the value of t-statistics that obtained from the bootstrapping method (Table 6). In the $\mathrm{H}_{1}$ hypothesis test, it showed that the value of t-statistics from the relationship between technology competencies and science teachers' TPACK of 3.22>1.96, then $\mathrm{H}_{0}$ was rejected. It means technology competencies have a positive relationship with the science teachers' TPACK. The value of t-statistics that obtained also showed that technology competencies have a significant effect on the science teachers' TPACK.

Furthermore, in the $\mathrm{H}_{2}$ hypothesis test showed that the t-statistic value on the interaction between technology competencies and teachers' attitudes towards science teachers' TPACK obtained a value of $5.83>1.96$, then $\mathrm{H}_{0}$ was rejected. It means the teachers' attitude is a moderator variable or able to moderate the relationship between technology competency and science teachers' TPACK. Table 6 also showed that the teachers' attitudes also have a significant effect on science teachers' TPACK. Therefore, based on the model that built and the results of hypothesis testing, showed that technology competencies, attitudes towards technology integration, and the relationship of competencies and attitudes towards technology integration are predictors of science teachers' TPACK.

The results obtained by this study are consistent with previous research on the relationship between technological competencies, attitudes in technology integration, and TPACK capabilities. Research conducted by Yerdelen-Damar et al. (2017) showed that the competencies and attitudes of teachers have a direct effect on teachers' TPACK. Besides, the research also showed that there was a positive influence between technological competencies and the attitude of teachers in technology integration. Other research results from Karaca et al. (2013) showed that technology competencies and teachers' attitudes have a direct effect on technology integration. The research also showed exciting results where technology competencies have a significant influence on teachers' attitudes and beliefs. It means the teachers will have positive attitudes and beliefs if they have good technology competencies. The results of these studies indicate that technology competencies and attitudes towards technology integration are predictors in technology integration. 
Specifically, technology competencies and attitudes towards technology integration affect the teacher's Technological Knowledge (TK). TK is the main component forming TPACK. The type of technology used as an indicator in this component is ICT. It was similar to the type of technology used as an indicator in technology competence and attitudes towards technology integration. According to the research results from Yurdakul and Coklar (2014), it showed that ICT usage had a significant effect on the teachers' TPACK. Specifically, ICT usage affects the TK of teachers. Therefore, it showed that the relationship formed from technology competencies and attitudes in technology integration towards TPACK was caused by indicators of TK components specifically consisting of ICT.

\section{Interpretation of interaction effects}

Interpretation of the two-way interaction effects using an Excel file template obtained from the Dawson (2019). The template facilitates researchers to interpret the moderating effects of teacher attitudes in the relationship between technology competency and TPACK. The results of the interpretation in the form of a chart shown in Figure 3.

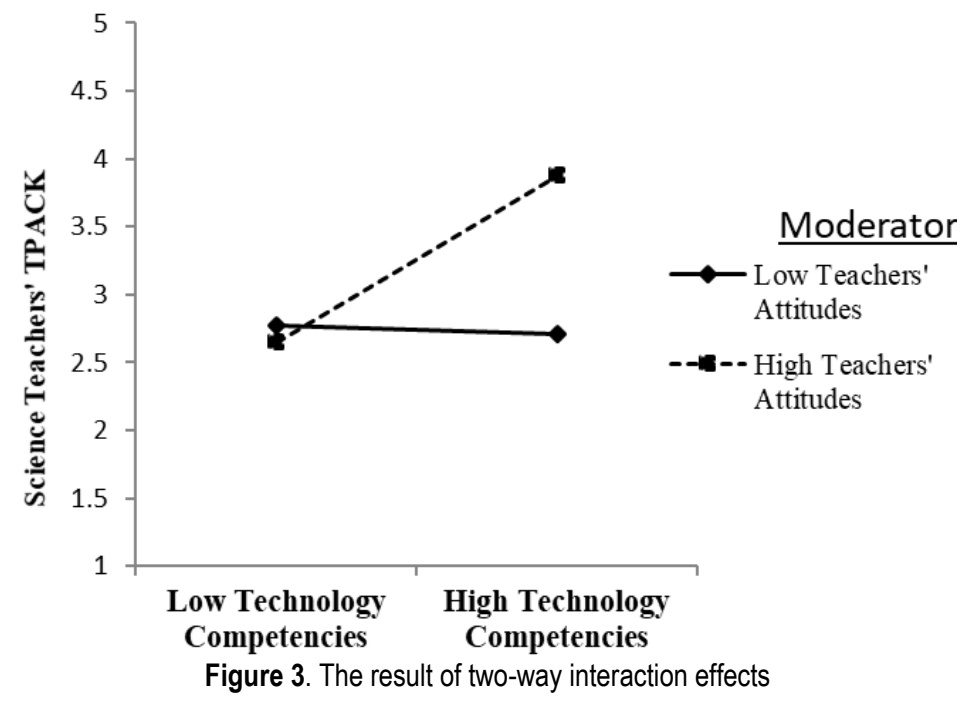

Figure 3 showed that the higher the teachers' attitude, then the higher the degree of technology competencies and TPACK. It means the teachers' attitude strengthens the positive relationship between technology competencies and science teachers' TPACK. These results indicated that the teachers' attitudes have an essential role in technology integration; in this case, it is strengthening the relationship between technology competencies and science teachers' TPACK.

Based on the research results, it appears that attitudes play an essential role in integrating technology. It caused by attitudes towards technology integration affected the acceptance and use of technology in learning activities (Scherer, Tondeur, Siddiq, \& Baran, 2018). However, this factor is still often ignored (Niederhauser \& Lindstrom, 2018). The government is still focused on providing technology tools and facilities. They consider technology integration to take place automatically when technology is available (Baturay et al., 2017; Ertmer, 1999; Niederhauser \& Lindstrom, 2018). Specifically, it can be seen from the "Smart City" program from the Aceh Province government. This program only focuses on providing internet services in all Aceh Province Vocational Schools (Saifullah, 2017).

According to Ertmer (1999), attitudes often ignored due to attitudes are the intrinsic factors of the teacher. Intrinsic factors are abstract and personal. Therefore, this problem is more challenging to solve than solving problems related to extrinsic factors (Baturay et al., 2017; Ertmer, 1999; Vongkulluksn, Xie, \& Bowman, 2018). This problem can be solved by choosing and using technology that often used by the teacher. So, the teachers are easy to integrate the technology into their learning activities. The statement is in line with the interview results with the Physics teacher stating that the teacher uses his smartphone as a learning media, by giving it to groups of students in alternately. This method was used to overcome the problem of technology availability and was obtained by the teacher when they take part in MGMP activities. This information indicated that the use of mobile learning must be encouraged in schools because of its easy to use (Yulisman, 2017). It showed that the teachers' positive attitude would emerge if the available technology is a technology 
that is acquainted with them, and the technology is accessible for them to use. Furthermore, the teachers' positive attitude will help them find ways to integrate technology into their learning activities.

According to Birkollu (2017) and Buabeng-Andoh (2012), the positive attitude of teachers in the application of technology will facilitate them in adopting and integrating technology into their learning activities. It means, if the teacher is interested in using technology, then they will find ways to integrate the technology into their learning activities. Therefore, instead of focusing on increasing the competence and ability to integrate teacher technology, it is imperative to pay attention to the teachers' attitudes on the use of technology. The results of interviews with Physics teachers also showed that training activities using technology for teachers should not be focused on how to use technology only, but how to use technology in learning activities.

The results of interviews from Biology teachers showed that teachers want to integrate technology, but they are still constrained by an organizational factor. Although he has good technology competencies and a positive attitude in technology integration, the process of integrating technology into learning activities cannot be performed because of constraints in school facilities, such as electricity, the lack of tools and complicated licensing in the use of technological tools. It means organizational factor can hamper individual factor in technology integration. According to Niederhauser (Niederhauser \& Lindstrom, 2018), five factors influence the integration of technology into learning activities, namely environmental, technological, individual, organizational, and pedagogical considerations.

\section{CONCLUSION}

Technology competencies have a positive relationship and a significant effect on the science teachers' TPACK. Furthermore, the variable of teachers' attitudes in technology integration is a moderator variable or able to moderate the relationship of technology competencies and science teachers' TPACK. The results from the interpretation of the interaction effects also indicated that the teachers' attitudes strengthen the positive relationship between technology competencies and science teachers' TPACK.

The results of this research indicated that the teachers' attitudes have an essential role in integrating technology into learning activities. Therefore, researchers, teachers, or education providers should not ignore teachers' attitudes. Furthermore, further information is needed on the influence of other factors that influence the integration of TPACK, especially in Indonesia.

\section{ACKNOWLEDGMENT}

We would like to thank Indonesia Endowment Fund for Education, abbreviated as LPDP (Lembaga Pengelola Dana Pendidikan), the Faculty of Teacher Training and Education-Universitas Syiah Kuala, Education and Culture Office of Kota Banda Aceh, and junior high school science teachers in Kota Banda Aceh for supporting us in order to collect research data.

\section{REFERENCES}

Agustin, R. R., Liliasari, Sinaga, P., \& Rochintaniawati, D. (2018). The investigation of science teachers' experience in integrating digital technology into science teaching. In Journal of Physics: Conference Series (Vol. 1013). doi: https://doi.org/10.1088/1742-6596/1013/1/012079

Anwar, Y., Rustaman, N. Y., Widodo, A., \& Redjeki, S. (2014). Kemampuan pedagogical content knowledge guru biologi yang berpengalaman dan yang belum berpengalaman. Jurnal Pengajaran MIPA, 19(1), 6973. doi: https://doi.org/10.18269/jpmipa.v19i1.426

Badan Standar Nasional Pendidikan. Standar kualifikasi akademik dan kompetensi guru, Peraturan Menteri Pendidikan Nasional Republik Indonesia Nomor 16 (2007). Indonesia: Menteri Pendidikan Nasional Republik Indonesia. Retrieved from http://vervalsp.data.kemdikbud.go.id/prosespembelajaran/file/Per mendiknas\%20No\%2016\%20Tahun\%202007.pdf

Baturay, M. H., Gökçearslan, Ş., \& Ke, F. (2017). The relationship among pre-service teachers computer competence, attitude towards computer-assisted education, and intention of technology acceptance. International Journal of Technology Enhanced Learning, 9(1), 1-13. doi: https://doi.org/10.1504/IJTEL. 2017.10003119

Bilici, S. C., Guzey, S. S., \& Yamak, H. (2016). Assessing pre-service science teachers' Technological 
Pedagogical Content Knowledge (TPACK) through observations and lesson plans. Research in Science and Technological Education, 34(2), 237-251. doi: https://doi.org/10.1080/02635143.2016.1144050

Birkollu, S. S., Yucesoy, Y., Baglama, B., \& Kanbul, S. (2017). Investigating the attitudes of pre-service teachers towards technology based on various variables. TEM Journal, 6(3), 578-583. doi: https://doi. org/10.18421/TEM63-20

Buabeng-Andoh, C. (2012). Factors influencing teachers' adoption and integration of information and communication technology into teaching: A review of the literature. International Journal of Education and Development Using Information and Communication Technology, 8(1), 136-155. Retrieved from https://files.eric.ed.gov/fulltext/EJ1084227.pdf

Chai, C. S., Koh, J. H. L., Tsai, C. C., \& Tan, L. L. W. (2011). Modeling primary school pre-service teachers' Technological Pedagogical Content Knowledge (TPACK) for meaningful learning with information and communication technology (ICT). Computers and Education, 57(1), 1184-1193. doi: https://doi.org/10. 1016/j.compedu.2011.01.007

Chow, P., \& Pepe, T. M. (2015). Teacher's attitudes towards technology in the classroom. ProQuest Dissertations and Theses, (April), 1-38. doi: https://doi.org/10.1002/ejoc.201200111

Dalal, M., Archambault, L., \& Shelton, C. (2017). Professional development for international teachers: Examining TPACK and technology integration decision making. Journal of Research on Technology in Education, 49(3-4), 117-133. doi: https://doi.org/10.1080/15391523.2017.1314780

Dawson, J. (2019). Interpreting interaction effects. Retrieved from http://www.jeremydawson.co.uk/slopes.htm

Deng, F., Chai, C. S., So, H. J., Qian, Y., \& Chen, L. (2017). Examining the validity of the Technological Pedagogical Content Knowledge (TPACK) framework for preservice chemistry teachers. Australasian Journal of Educational Technology, 33(3), 1-14. doi: https://doi.org/10.14742/ajet.3508

Drajati, N. A., Tan, L., Haryati, S., Rochsantiningsih, D., \& Zainnuri, H. (2018). Investigating English language teachers in developing TPACK and multimodal literacy. Indonesian Journal of Applied Linguistics, 7(3), 575-582. doi: https://doi.org/10.17509/ijal.v7i3.9806

Ertmer, P. A. (1999). Addressing first- and second-order barriers to change: Strategies for technology integration. Educational Technology Research and Development, 4(47), 47-61. Retrieved from https: //link.springer.com/article/10.1007/BF02299597

Fraenkel, J. R., Wallen, N. E., \& Hyun, H. H. (2012). How to design and evaluate research in education. New York: McGraw-Hill. Retrieved from https://www.academia.edu/3642866/How_to_Design_and_Evaluate_ Research_in_Education

Ghozali, I. (2014). Structural equation modelling: Metode alternatif dengan Partial Least Squares (PLS) (4th ed.). Semarang: Badan Penerbit Universitas Diponegoro. Retrieved from https://www.researchgate.net/ profile/Imam_Ghozali/publication/289674653_Structural_Equation_Modeling_Metode_Alternatif_dengan _Partial_Least_Squares_PLS/links/5691e1ec08aee91f69a5224e/Structural-Equation-Modeling-MetodeAlternatif-dengan-Partial-Least-Squa

Ghozali, I., \& Latan, H. (2015). Partial least squares, konsep, teknik dan aplikasi menggunakan program SmartPLS 3.0 untuk penelitian empiris (2nd ed.). Semarang: Badan Penerbit Universitas Diponegoro. Retrieved from http://onesearch.id/Record/IOS3107.UMS:57482

Hair, J. F. J., Hult, G. T. M., Ringle, C., \& Sarstedt, M. (2014). A primer on Partial Least Squares Structural Equation Modeling (PLS-SEM). Long Range Planning (Vol. 46). California: SAGE Publications. Retrieved from https://www.researchgate.net/profile/Qais_Almaamari3/post/How_can_I_justify_in_a_ reflective_second-order_construct_to_drop_some_dimensions_which_not_perform_well/attachment/5a 79c437b53d2f0bba5042d9/AS\%3A591053426008064\%401517929526701/download/3b.+Hair+Bo

Huda, I., Yulisman, H., Nurina, C. I. E., Erni, F., \& Abdullah, D. (2018). Investigating pre-service teachers about their competencies, experiences, and attitudes towards technology integration. Journal of Physics: Conference Series, 1114(1), 012033. doi: https://doi.org/10.1088/1742-6596/1114/1/012033

Joo, Y. J., Park, S., \& Lim, E. (2018). Factors influencing preservice teachers' intention to use technology: TPACK, teacher self-efficacy, and technology acceptance model. Educational Technology and Society, 21(3), 48-59. doi: https://doi.org/10.1016/S0735-1097(03)00623-5

Karaca, F., Can, G., \& Yildirim, S. (2013). A path model for technology integration into elementary school settings in Turkey. Computers and Education, 68, 353-365. doi: https://doi.org/10.1016/j.compedu.20 13.05.017

Kimmons, R. (2015). Examining TPACK's theoretical future. Journal of Technology and Teacher Education, 23(1), 53-77. Retrieved from https://eric.ed.gov/?id=EJ1051712 
Kimmons, R., \& Hall, C. (2018). How useful are our models? Pre-service and practicing teacher evaluations of technology integration models. TechTrends, 62(1), 29-36. doi: https://doi.org/10.1007/s11528-017022 78

Koehler, M. J., Mishra, P., \& Cain, W. (2013). What is Technological Pedagogical Content Knowledge (TPACK)? Journal of Education, 193(3), 13-19. doi: https://doi.org/10.1016/j.compedu.2010.07.009

Koh, J. H. L., Chai, C. S., \& Tsai, C. C. (2013). Examining practicing teachers' perceptions of Technological Pedagogical Content Knowledge (TPACK) pathways: A structural equation modeling approach. Instructional Science, 41(4), 793-809. doi: https://doi.org/10.1007/s11251-012-9249-y

Latan, H., \& Ramli, N. A. (2013). The results of Partial Least Squares-Structural Equation modelling analyses (PLS-SEM). SSRN Electronic Journal, (October 2017), 2-35. doi: https://doi.org/10.2139/ssrn.2364191

Magana, S., \& Marzano, R. J. (2014). Enhancing the art \& science of teaching with technology (classroom strategies). Bloomington: Marzano Research. Retrieved from https://www.goodreads.com/en/book/ show/18474733-enhancing-the-art-science-of-teaching-with-technology

Mahdum. (2015). Technological Pedagogical and Content Knowledge (TPACK) of English teachers in Pekanbaru, Riau, Indonesia. Mediterranean Journal of Social Sciences, 6(5), 168-176. doi: https://doi. org/10.5901/mjss.2015.v6n5s1p168

Miskiah, M., Suryono, Y., \& Sudrajat, A. (2019). Integration of information and comunication technology into Islamic Religious Education Teacher Training. Cakrawala Pendidikan, 38(1), 130-140. doi: https://doi. org/10.21831/cp.v38i1.23439

Niederhauser, D. S., \& Lindstrom, D. L. (2018). Instructional technology integration models and frameworks: Diffusion, competencies, attitudes, and dispositions. In J. Voogt, G. Knezek, R. Christensen, \& K.-W. Lai (Eds.), Handbook on Information Technology in Primary and Secondary Education (pp. 335-355). Cham: Springer. doi: https://doi.org/10.1007/978-3-319-71054-9_23

Nofrion, N., Wijayanto, B., Wilis, R., \& Novio, R. (2018). Analisis Technological Pedagogical and Content Knowledge (TPACK) guru geografi di Kabupaten Solok, Sumatera Barat. JURNAL GEOGRAFI, 10(2), 105-116. doi: https://doi.org/10.24114/jg.v10i2.9070

Pusparini, F., Riandi, R., \& Sriyati, S. (2017). Developing Technological Pedagogical Content Knowledge (TPACK) in animal physiology. In Journal of Physics: Conf. Series (Vol. 895, p. 012052). IOP Publishing. doi: https://doi.org/10.1088/1742-6596/895/1/012059

Ringle, C., Wende, W. S., \& Becker, J.-M. (2015). SmartPLS 3. Boenningstedt: SmartPLS GMBH. Retrieved from http://www.smartpls.com

Saifullah, M. (2017). Ini terobosan bidang pendidikan 100 hari kerja Irwandi-Nova. Retrieved from http://portalsatu.com/read/news/ini-terobosan-bidang-pendidikan-100-hari-kerja-irwandi-nova-36478

Sánchez, A.-B., Marcos, J.-J. M., González, M., \& GuanLin, H. (2012). In service teachers' attitudes towards the use of ICT in the classroom. Procedia - Social and Behavioral Sciences, 46, 1358-1364. doi: https://doi.org/10.1016/j.sbspro.2012.05.302

Scherer, R., Tondeur, J., Siddiq, F., \& Baran, E. (2018). The importance of attitudes toward technology for pre-service teachers' technological, pedagogical, and content knowledge: Comparing structural equation modeling approaches. Computers in Human Behavior, 80, 67-80. doi: https://doi.org/10.1016/ j.chb.2017.11.003

Sholihah, M., \& Yuliati, L. (2016). Peranan TPACK terhadap kemampuan calon guru Fisika dalam pembelajaran post-pack. Jurnal Pendidikan: Teori, Penelitian, Dan Pengembangan, 1(2), 144-153. Retrieved from http://journal.um.ac.id/index.php/jptpp/article/view/6115

Sugiyono. (2016). Metode penelitian pendidikan (Pendekatan kuantitatif, kualitatif, dan R\&D). Bandung: Alfabeta. Retrieved from http://pustaka.unm.ac.id/opac/detail-opac?id=35458

Supriyadi, S., Bahri, S., \& Waremra, R. S. (2018). Kemampuan Technological Pedagogical Content Knowledge (TPACK) mahasiswa pada matakuliah strategi belajar mengajar fisika. Jurnal Inspirasi Pendidikan, 8(2), 1-9. doi: https://doi.org/10.21067/jip.v8i2.2632

Valtonen, T., Kukkonen, J., Kontkanen, S., Mäkitalo-Siegl, K., \& Sointu, E. (2018). Differences in pre-service teachers' knowledge and readiness to use ICT in education. Journal of Computer Assisted Learning, 34(2), 174-182. doi: https://doi.org/10.1111/jcal.12225

Valtonen, T., Sointu, E., Kukkonen, J., Kontkanen, S., Lambert, M. C., \& Mäkitalo-Siegl, K. (2017). TPACK updated to measure pre-service teachers' Twenty-First Century Skills. Australasian Journal of Educational Technology, 33(3), 15-31. doi: https://doi.org/10.14742/ajet.3518

Valtonen, T., Sointu, E., Mäkitalo-Siegl, K., \& Kukkonen, J. (2015). Developing a TPACK measurement 
instrument for 21 st century pre-service teachers. Retrieved from https://journals.hioa.no/index.php/ seminar/article/view/2353

Vongkulluksn, V. W., Xie, K., \& Bowman, M. A. (2018). The role of value on teachers' internalization of external barriers and externalization of personal beliefs for classroom technology integration. Computers and Education, 118, 70-81. doi: https://doi.org/10.1016/j.compedu.2017.11.009

Widodo, A. (2017). Experienced biology teachers' Pedagogical Content Knowledge (PCK) on photosynthesis. In AIP Conference Proceedings (Vol. 1848, p. 060017). American Institute of Physics. doi: https://doi. org/10.1063/1.4983985

Wong, K. K.-K. (2013). Partial Least Squares Structural Equation modeling (PLS-SEM) techniques using SmartPLS. Marketing Bulletin, 24, 1-32. doi: https://doi.org/10.1097/MNM.0b013e328332f801

Yanti, H., Setiawan, A., Nurhabibah, \& Yannuar. (2018). Teacher's perception about the use of ELearning/Edmodo in educational activities. In IOP Conference Series: Materials Science and Engineering (Vol. 306). doi: https://doi.org/10.1088/1757-899X/306/1/012055

Yavuz, S. (2005). Developing a technology attitude scale for pre-service chemistry teachers. The Turkish Online Journal of Educational Technology (TOJET), 4(1), 17-25. Retrieved from http://tojet.net/articles/ v4i1/412.pdf

Yerdelen-Damar, S., Boz, Y., \& Aydın-Günbatar, S. (2017). Mediated effects of technology competencies and experiences on relations among attitudes towards technology use, technology ownership, and self efficacy about Technological Pedagogical Content Knowledge. Journal of Science Education and Technology, 26(4), 394-405. doi: https://doi.org/10.1007/s10956-017-9687-z

Yulisman, H. (2017). Perceptions of education lecturers in the implementation of mobile learning. IJAEDUInternational E-Journal of Advances in Education, 3(9), 518-524. doi: https://doi.org/10.18768/ijaedu. 370413

Yurdakul, I. K., \& Coklar, A. N. (2014). Modeling preservice teachers' TPACK competencies based on ICT usage. Journal of Computer Assisted Learning, 30(4), 363-376. doi: https://doi.org/10.1111/jcal.12049 